\title{
Status of major diseases of brinjal and tomato in charland of Jamalpur and Sherpur districts of Bangladesh
}

\author{
Mohammad Monirul Hasan Tipu ${ }^{1 *}$, Raunak Jahan², Jubaidur Rahman³, Mukaddasul Islam Riad", \\ Md. Mashiur Rahman ${ }^{5} \&$ K. M. Eadun Nabi ${ }^{6}$ \\ ${ }^{1}$ Plant Pathology Division, Bangladesh Agricultural Research Institute (BARI), Joydebpur, Gazipur-1701, Bangladesh \\ ${ }^{2}$ Department of Aquaculture, Bangladesh Agricultural University (BAU), Mymensingh-2202, Bangladesh \\ ${ }^{3}$ Agronomy Division, Regional Agricultural Research Station, Bangladesh Agricultural Research Institute (BARI), Jamalpur-2000, Bangladesh \\ ${ }^{4}$ Plant Genetic Resources Centre, Regional Agricultural Research Station, Bangladesh Agricultural Research Institute (BARI), Jamalpur-2000, \\ Bangladesh \\ ${ }^{5}$ Agricultural Engineering Division, Regional Agricultural Research Station, Bangladesh Agricultural Research Institute (BARI), Jamalpur-2000, \\ Bangladesh \\ ${ }^{6}$ Plant Pathology Division, Bangladesh Institute of Nuclear Agriculture (BINA), Mymensingh-2202, Bangladesh \\ *Email: tipubari2013@yahoo.com
}

\section{ARTICLE HISTORY}

Received: 09 October 2020

Accepted: 10 December 2020

Published: 15 January 2021

KEYWORDS

Brinjal

Tomato

Bacterial wilt

Phomopsis blight

Viral diseases

\section{ABSTRACT}

Brinjal and tomato, both of these Solanaceous crops, suffer from different diseases based on their surrounding environment. In charland ecosystem, due to the current trend of climate change these two crops have become vulnerable to disease infection. A comprehensive survey was conducted in Jamalpur and Sherpur districts to measure the severity of major diseases of brinjal and tomato in this region during the rabi season of 2018-19. This survey was based on farmers' fields targeting 10 different locations where brinjal and tomato were grown extensively. Data were collected from randomly selected farmer's vegetable fields where incidence and severity were recorded. Through the survey, five (5) diseases based on their incidence and severity were categorized as major diseases in studied areas. Bacterial wilt of brinjal $(60 \%)$ and viral disease of tomato $(41.67 \%)$ were found to be higher in incidence. This was a major limiting factor for decreasing total brinjal and tomato production in the charland of Jamalpur and Sherpur. Wilting of tomato (20\%), viral disease of brinjal $(20 \%)$ and phomopsis blight of brinjal (13.33\%) were medium in incidence at different locations. Farmers of these areas found these diseases to be a serious threat to future cultivation and expansion of brinjal and tomato in charland.

\section{Introduction}

Bangladesh is a subtropical country. The climate of this country is favourable for the production of different vegetables. Brinjal (Solanum melongena L.) and tomato (Solanum lycopersicum L.) are two important vegetables in the world as well as in Bangladesh for their commercial and nutritional value (1). In Bangladesh, the district of Jamalpur, Sherpur, Mymensingh, Rangpur, Faridpur, Rajshahi, Pabna and Jashore are major cultivation areas of brinjal and tomato. Jamalpur and Sherpur are famous for their production and fulfill the demand within the country and abroad. Brinjal and tomato are winter crops but they also grow in summer as different hybrid and high yielding varieties are available.
The climatic condition of Bangladesh is also favourable for different disease development of vegetables. More than 454 diseases in around 100 cultivated crops have so far been recorded in Bangladesh (2). The diseases cause substantial losses to crops. These enormous losses hamper the total yield production of the country. Generally, $30-50 \%$ loss is incurred due to the disease (3). Similarly, the situation is also congenial and favourable for the pathogens to various diseases of brinjal and tomato. Due to the current trend of climate change, different crops have become vulnerable to disease infection. Therefore, a number of diseases may pose a threat that can cause yield reduction of brinjal and tomato in charland

(C) Tipu et al (2021). This is an open-access article distributed under the terms of the Creative Commons Attribution License, which permits unrestricted use, distribution and reproduction in any medium, provided the original author and source are credited (https://creativecommons.org/licenses/by/4.0/).

To cite this article: Tipu M M H, Jahan R, Rahman J, Riad M I, Rahman M M, Nabi K M E. Status of major diseases of brinjal and tomato in charland of Jamalpur and Sherpur districts of Bangladesh. Plant Science Today. 2021;8(1):161-165. https://doi.org/10.14719/pst.2021.8.1.988 
ecosystem. Many known and unknown pathogens are responsible for such kind of diseases.

The magnitude of yield loss depends upon the intensity of the disease. The amount of crop losses owing to a particular disease varied from place to place because of the existence of different races, biotypes, or strains of the pathogen (4). Jamalpur region includes charland districts of Bangladesh. The charland areas of Jamalpur and Sherpur fall under the agro-ecological zone number 8 and 9 (5). The agroclimatic conditions of the region are different from the other parts of the country. Farmers of the Jamalpur region are facing this problem for years. So, this attempt was made for the survey of the incidence of major diseases of brinjal and tomato at Jamalpur and Sherpur districts.

\section{Materials and Methods}

Jamalpur is located between 24\%5'10" North and between $89^{\circ} 56^{\prime} 53^{\prime \prime}$ East. It shares an international border with the Indian state of Meghalaya in the North East. It is surrounded by Kurigram and Sherpur districts in the North, Tangail district in the South, Mymensingh and Sherpur districts in the East, Jamuna River, Bogra, Sirajganj and Gaibandha districts in the West. The main town is situated on the bank of the river Brahmaputra, 140 kilometers (87 mi) north of Dhaka, the national capital. Sherpur district is bounded on the north by India, on the east by Mymensingh district, on the south and west by Jamalpur district. Sherpur has a latitude of $25^{\circ} 1^{\prime} 9.86^{\prime \prime}$ North and a longitude of $90^{\circ} 0^{\prime} 49.44^{\prime \prime}$ East.

Climate is fluctuating in the whole year in charland of Jamalpur and Sherpur. It is cold from November to March while it is hot from April to June, and the remaining months are with moderate temperature. The total annual average rainfall was about $612 \mathrm{~mm}$ and $1084 \mathrm{~mm}$ in Jamalpur and Sherpur respectively during the study period. The major amount of rainfall occurs between June and August. The average mean annual temperature varied from $17^{\circ}$ to $42^{\circ} \mathrm{C}$ in Jamalpur and $12^{\circ}$ to $36^{\circ} \mathrm{C}$ in Sherpur.

The survey work was conducted in the farmer's field at Jamalpur and Sherpur districts (Fig. 1) during the winter season of 2019. The incidence and severity of different diseases were recorded. Disease assessments were done in 30 farmer's fields in 10 locations of 4 upazilas of the region. The farmers were selected randomly to avoid possible biases. The study areas were Jamalpur sadar, Melandah, Islampur and Sherpur sadar upazila. In each area, 3 vegetable fields were evaluated. Diseases were recorded in rabi season on the individual plant, both leaf and fruit.

Infected plant samples of leaves, fruits and twigs have been collected in brown paper packets and brought to the laboratory for identification of pathogens. All materials which are used in this experiment were sterilized using ethyl alcohol except the samples. The diseased parts were cut into small pieces of $3 \mathrm{~mm}$ diameter with some healthy part. The small pieces were washed with tap water and surface sterilized with $10 \% \mathrm{NaOCl}$ for 30 to $60 \mathrm{sec}$, again rinsed with sterile water and blotted to dry on clean tissue paper. After drying, three pieces were aseptically placed into Petri dishes containing Potato Dextrose Agar (PDA) medium. Then, the inoculated Petri dishes have been marked with the name of the sample and date of inoculation and incubated at a temperature of $25{ }^{\circ} \mathrm{C}$ for 5 days, until pathogen proliferation on the medium surface (6). For bacterial identification, bacterial ooze mixed with distilled water was streaked on Casamino acid-PeptoneGlucose (CPG) medium and incubated at $28{ }^{\circ} \mathrm{C}$ for 48 hrs.

Identifications were carried out on the basis of characterization of colonies and have also been examined under a compound microscope with $40 \mathrm{X}$ magnification $(7,8)$.

Disease assessment was made in three unit areas (100 plants from each vegetable field) selected randomly. In every unit area, the total number of the diseased plant along with the number of corresponding healthy plants were counted separately. The results were expressed in percentage. The formula in calculating the disease incidence and severity is (9):

$\%$ Leaf/fruit infection= $($ Number leaves or fruits infected $\times 100$ )/Total number of leaves or fruit counted.

PDI for severity $=($ Sum of all disease ratings $\times$ 100)/(Total number of leaves or fruits $\times$ maximum rating value).

The maximum rating scale (1-5) has been used for the assessment of disease severity (Table 1).

Table 1. Rating scale for assessment of disease severity

\begin{tabular}{cc}
\hline Rating Scale & Disease Percentage \\
\hline 1 & $1-5$ \\
\hline 2 & $5-25$ \\
\hline 3 & $25-50$ \\
\hline 4 & $50-75$ \\
\hline 5 & $75-100$ \\
\hline
\end{tabular}

For the estimation of leaf and fruit area diseased, the whole fruit and leaf surface area were considered as 100 and thereby the infected area was determined by eye estimation for percent of disease index (PDI). Disease incidence was graded as low (up to $10 \%$ ), medium (up to $30 \%$ ) and high (more than 30\%) (10). Data were collected at the seedling, growing and maturity stages of plant growth of brinjal and tomato. All the collected data were subjected to analysis of variance at an end of the study by using the STAR (version 2.0.1) software application.

\section{Results}

Different types of plant diseases were found in surveyed areas (Fig. 2). Bacterial wilt of brinjal was a major disease for reducing brinjal cultivation in Jamalpur and Sherpur (Table 2). On the other hand, viral diseases of tomato was a major threat for 


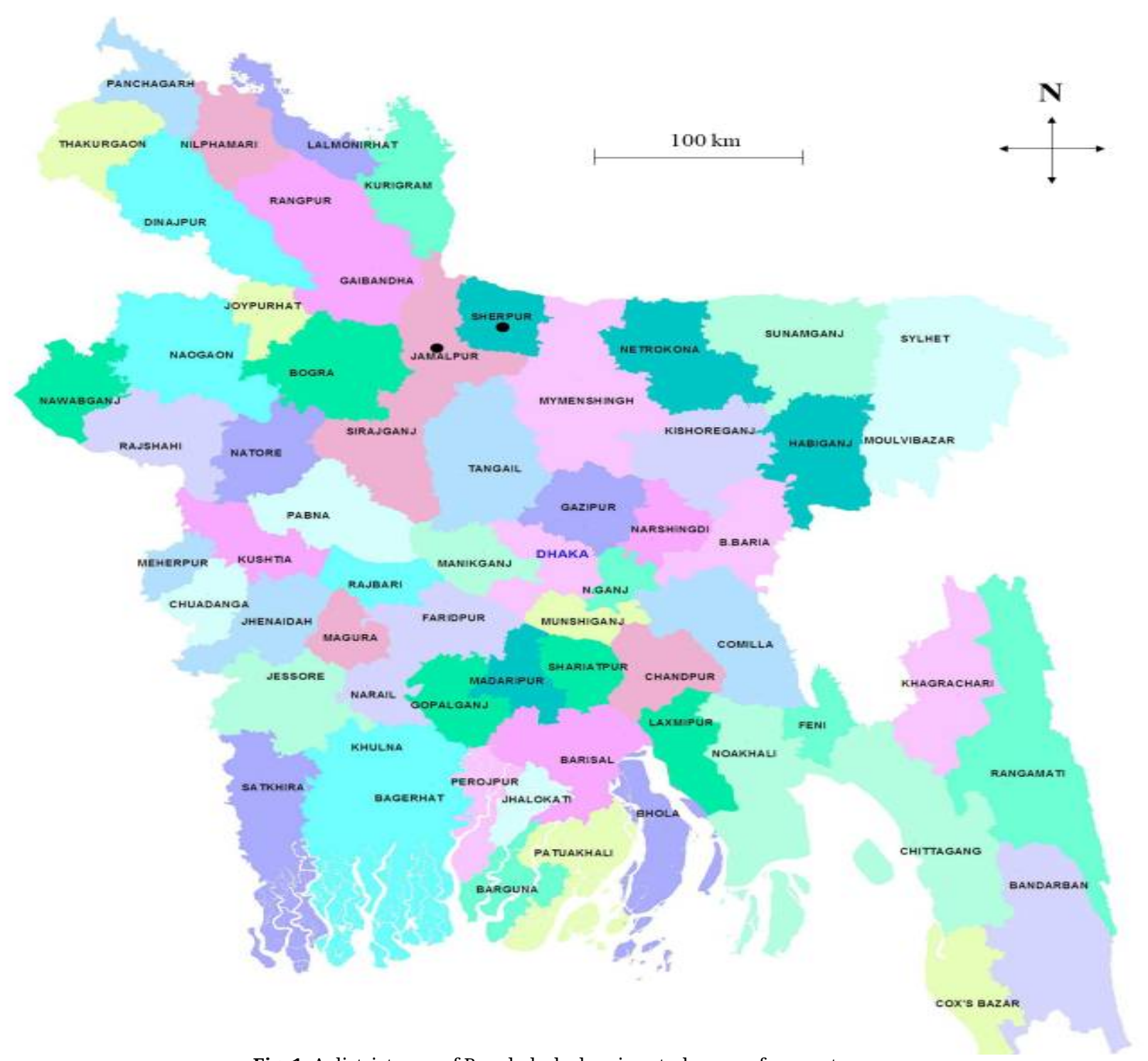

Fig. 1. A district map of Bangladesh showing study area of current survey.

$(\bullet)$ Area under field sample collection.

tomato growers in this region. Bacterial wilt of brinjal (60\%) and viral disease of tomato (41.67\%) were found to be higher in incidence and severity (16.40\% for bacterial blight of brinjal and $8.36 \%$ for viral disease of tomato). The incidence of wilting in tomato (20\%) at surveyed areas was medium having a severity level of $17.90 \%$. The viral disease of brinjal in the region was also medium (20\%) showing a lower severity level of $1.73 \%$. Brinjal farmers of Jamalpur and Sherpur districts also experienced a medium level of phomopsis blight disease in their crop field showing $13.33 \%$ incidence and $5.23 \%$ severity. There was a lower incidence $(7.33 \%)$ and severity $(0.67 \%)$ of the little leaf of brinjal at a few farmers' fields of surveyed location.

\section{Discussion}

Based on incidence and severity data surveyed diseases were categorized as high to medium (Table 2). It was found that bacterial wilt of brinjal and viral disease of tomato was a great threat for their cultivation in charland of Jamalpur and Sherpur showing the high status of their prevalence. It could be the result of favourable environment of charland ecosystem and farmers may have used diseaseinfected seeds for sowing. In charland, especially in Jamalpur and Sherpur, the day-night temperature fluctuation is noticeable and this weather phenomenon is a major factor for disease development (11). Temperature is an important factor which affects the growth and aggressiveness of pathogen and expression of symptoms in the plant. Ralstonia solanacearum causing wilt disease is most severe on plants when temperature ranges between 25 and $35^{\circ} \mathrm{C}$ and its aggressiveness decreases, either exceeds $35{ }^{\circ} \mathrm{C}$ or below $18{ }^{\circ} \mathrm{C}$ temperature (12). The disease information of the study on incidence and severity agreed with the reviewed literature. Bacterial wilt can cause up to $90 \%$ yield loss and Tijjani and his team found $37 \%$ yield loss in tomato by bacterial wilt in the dry season (13). According to a researcher (14), about $15-20 \%$ in general and 30-50\% in a severe case of fruit rots of eggplant were caused seriously due to Phomopsis blight. About 60\% plant infection and 20\% fruit infection owing to Phomopsis vexans was recorded in the Chittagong region (15). Charland weather with variation in humidity and temperature affected Phomopsis fruit rot of brinjal 


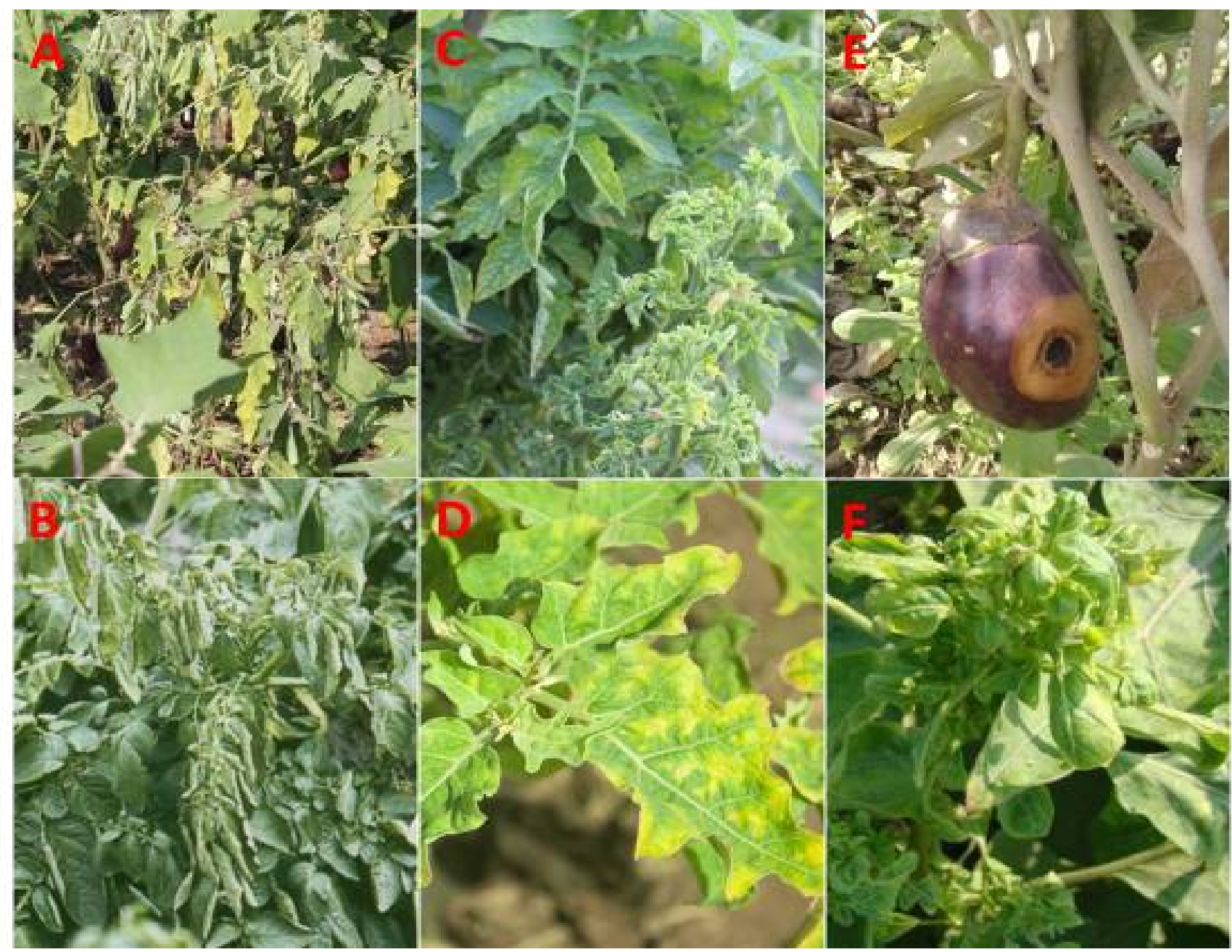

Fig. 2. Different plant diseases found during survey. A) Bacterial wilt of Brinjal, B) Bacterial wilt of Tomato, C) Viral disease of Tomato, D) Viral disease of Brinjal, E) Phomopsis blight of Brinjal, F) Little leaf of Brinjal.

Table 2. Incidence, severity and status of different diseases of brinjal and tomato.

\begin{tabular}{lccc}
\hline Diseases & \%Incidence & \%Severity & Status \\
\hline Bacterial wilt of Brinjal & 60.00 & 16.40 & High \\
\hline Bacterial wilt of Tomato & 20.00 & 17.90 & Medium \\
\hline Viral disease of Brinjal & 20.00 & 1.73 & Medium \\
\hline Viral disease of Tomato & 41.66 & 8.36 & High \\
\hline Phomopsis blight of Brinjal & 13.33 & 5.23 & Medium \\
\hline Little leaf of Brinjal & 7.33 & 0.67 & Low \\
\hline CV\% & 12.44 & 7.37 & \\
\hline
\end{tabular}

(16). Other researchers (17-19) stated that the amount of crop and fruit losses to a particular disease varied from place to place because of the existence of different races, biotypes or strains of the pathogen due to changing climate. So, the incidence and severity of vegetables and fruits can differ in the different locations of Jamalpur and Sherpur. It was mostly similar to the record of study against the disease in the study areas. But, no detailed research findings on disease records were done keenly in the Jamalpur regions previously.

\section{Conclusion}

From the survey report, it was found that Jamalpur and Sherpur districts were at high risk of bacterial wilt of brinjal and viral disease of tomato due to their geographic location and climatic condition. So, necessary precautions should be taken to control these diseases at the economic threshold level in the region. It is highly advised to follow crop rotation of Solanaceous crop with non-Solanaceous crop to reduce disease incidence and severity.

\section{Acknowledgements}

This experiment was funded by Bangladesh Agricultural Research Institute, Gazipur, Bangladesh from the GoB fund.

\section{Authors' contributions}

MMHT: conceptualization, investigation, methodology, writing original draft, formal analysis, supervision, validation, writing review and editing, 
RJ: resources, formal analysis, data curation, writing review and editing, JR: writing review and editing, resources, software, visualization, MIR: funding acquisition, software, MMR: writing review and editing, resources, software, visualization, data curation, KMEN: writing review and editing, resources. All authors read and approved the final manuscript.

\section{Conflict of interests}

The authors declare that they have no known competing financial interests or personal relationships that could have appeared to influence the work reported in this paper.

\section{References}

1. Rahman MZ, Kabir H, Khan M. A study on brinjal production in Jamalpur district through profitabilityanalysis and factors affecting the production. Bangladesh Agril Univ Journal. 2016;14(1):113-18. https://doi.org/10.3329/jbau.v14i1.30605

2. Anonymous. Annual Report (2004-2005). Plant Pathology Division, Bangladesh Agricultural Research Institute, Gazipur. 2006.

3. Khan NU. Studies on epidemiology, seed-borne nature and management of Phomopsis fruit rot of brinjal. Plant Pathology, Masters [thesis]. Mymensingh (BD): Bangladesh Agricultural University; 1999;25-40.

4. Sastry MNL, Hegde RK. Variability of Phytophthora species obtained from plantation of Karnataka. Indian Phytopath. 1989;42(3):421-25.

5. Khatun A, Parvin N, Dewan MMR, Saha A. Cropping Patterns in Mymensingh Region: Diversity, Constraint and Potential. Bangladesh Rice J. 2017;21(2):217-35. https://doi.org/10.3329/brj.v21i2.38208

6. ISTA, International Seed Testing Association. International rules for seed testing. Seed Science and Technology. 1976;4:51177.

7. Aneja KR, editor. Experiment in microbiology, plant pathology and biotechnology. 4th Ed, India: New International (P) Limited Publisher; 2004;121-28.

8. Rifai MA, editor. A revision of the genus Trichoderma. Kew: Commonwealth Mycological Institute; 1969.
9. Hossain MT, Hossain SMM, Bakr MA, Rahman AKMM, Uddin SN. Survey on major diseases of vegetable and fruit crops in chittagong region. Bangladesh J Agril Res. 2010;35(3):423-29. https://doi.org/10.3329/bjar.v35i3.6449

10. Anonymous. Rating scale and severity index of crop diseases. Bangladesh Phytopathological Society, Plant Pathology Division, Bangladesh Agricultural Research Institute. 2008;131.

11. Velásquez AC, Christian DMC, Sheng YH. Plant and pathogen warfare under changing climate conditions. Curr Biol. 2018;28(10):619-34. https://doi.org/10.1016/j.cub.2018.03.054

12. Singh D, Yadav DK, Shweta S, Garima C. Effect of temperature, cultivars, injury of root and inoculums load of Ralstonia solanacearum to cause bacterial wilt of tomato, Archives of Phytopathology and Plant Protection. 2014;47(13):1574-83. https://doi.org/10.1080/03235408.2013.851332

13. Tijjani A, Bashir KA, Gurama AU, Adebitan SA. Potential impact of some cultural practices on incidence and severity of Ralstonia solanacearum, causing bacterial wilt disease in greenhouse tomatoes. Internat J Curr Sci Stud. 2018;2:1-7.

14. Das BH. Studies on Phomopsis in the fruit of brinjal. Plant Pathology, Masters [thesis]. Mymensingh (BD): Bangladesh Agricultural University; 1998;33-44.

15. Meah MB. Development of an integrated approach for management of Phomopsis blight and fruit rot of eggplant in Bangladesh. Final research report (2001-2006). Department of Plant Pathology, Bangladesh Agricultural University, Mymensingh, Bangladesh. 2007;102.

16. Islam SK, Sintansu P, Pan S. Effect of humidity and temperature on Phomopsis fruit rot of brinjal. Environment and Ecology. 1990;8(4):1309-10.

17. Kybartaitė J, Šernaitė L, Rasiukevičiūtè N, Valiuškaitė A. Plants and fungal pathogens under climate change, a review. Optimization of ornamental and garden plant assortment, technologies and environment. 2020;11(16):37-44. Available from: http://ojs.kaunokolegija.lt/index.php/DTAO/article/view/370/414

18. Potrykus M, Decorosi F, Perkowska I, Viti C, Mengoni A, Hugouvieux-Cotte-Pattat N, Lojkowska E. The metabolic shift in highly and weakly virulent Dickeya solani strains is more affected by temperature than by mutations in genes encoding global virulence regulators, FEMS Microbiology Ecology. 2020;96(3):fiaa023. https://doi.org/10.1093/femsec/fiaa023

19. Wang HC, Guo H, Cai L, Cai LT, Guo YS, Ding W. Effect of temperature on phenotype characterization of Ralstonia solanacearum from tobacco, Can J Plant Pathol. 2020;42(2):16481. https://doi.org/10.1080/07060661.2019.1654547 